\title{
Different techniques for urinary protein analysis of normal and lung cancer patients
}

\author{
Payungsak Tantipaiboonwong 1,2 , Supachok Sinchaikul ${ }^{1}$, Supawadee Sriyam ${ }^{1,2}$, \\ Suree Phutrakul ${ }^{2}$ and Shui-Tein Chen ${ }^{1,3}$ \\ ${ }^{1}$ Institute of Biological Chemistry, Academia Sinica, Taipei, Taiwan \\ 2 Department of Chemistry, Faculty of Science, Chiang Mai University, Chiang Mai, Thailand \\ ${ }^{3}$ Institute of Biochemical Sciences, College of Life Science, National Taiwan University, Taipei, Taiwan
}

\begin{abstract}
Many components in urine are useful in clinical diagnosis and urinary proteins are known as important components to define many diseases such as proteinuria, kidney, bladder and urinary tract diseases. In this study, we focused on the comparison of different sample preparation methods for isolating urinary proteins prior to protein analysis of pooled healthy and lung cancer patient samples. Selective method was used for preliminary investigation of some putative urinary protein markers. Urine samples were passed first through a gel filtration column (PD-10 desalting column) to remove high salts and subsequently concentrated. Remaining interferences were removed by ultrafiltration or four precipitation methods. The analysis of urinary proteins by high-performance liquid chromatography and sodium dodecyl sulfate-polyacrylamide gel electrophoresis showed many similarities in profiles among preparation methods and a few profiles were different between normal and lung cancer patients. In contrast, the results of two-dimensional gel electrophoresis (2-DE) showed more distinctly different protein patterns. Our finding showed that the sequential preparation of urinary proteins by gel filtration and ultrafiltration could retain most urinary proteins which demonstrated the highest protein spots on 2-D gels and able to identify preliminary urinary protein markers related to cancer. Although sequential preparation of urine samples by gel filtration and protein precipitation resulted in low amounts of proteins on 2-D gels, high $M_{\mathrm{r}}$ proteins were easily detected. Therefore, there are alternative choices for urine sample preparation for studying the urinary proteome and identifing urinary protein markers important for further preclinical diagnostic and therapeutic applications.
\end{abstract}

\section{Keywords:}

Lung cancer / Sample preparation / Two-dimensional gel electrophoresis / Urinary protein markers / Urine

\section{Introduction}

Human biological fluids contain various types of markers and these biomarkers are useful for prognosis, diagnosis and drug development for many diseases. Urine is a human

Correspondence: Professor Dr. Shui-Tein Chen, Institute of Biological Chemistry (RM707), Academia Sinica, 128 Yen Chiu Yuan Rd., Sec II, Nankang, Taipei, 11529, Taiwan

E-mail: bcchen@gate.sinica.edu.tw

Fax: +886-27883473

Abbreviations: DTE, dithioerythreitol; GM2AP, GM2 activator protein; TTR, transthyretin
Received: May 30, 2004 Revised: November 10, 2004 Accepted: November 15, 2004 sample that is easily obtained in clinical diagnosis. Some components in urine were used to analyze different patterns between normal and cancer patients such as nucleosides by RP-HPLC [1, 2] and CE [3], and for monitoring urinary tamoxifen and its metabolites in breast cancer treatment [4]. There are many ongoing studies looking for disease-related biomarkers in urine because urinary protein is one of the important components that can define a diseased state.

In the present study, many proteomic techniques were used to investigate urinary protein markers. Proteome maps of human normal urinary proteins were constructed to identify proteins normally found in urine [5-7]. There are few studies which use urine to compare normal and diseased 
proteomics techniques to find out some urinary protein markers from normal and diseased states such as inflamed pilonidal abscess diseased [8] and renal diseased [9]. In bladder cancer, a putative urinary marker was used for the followup of patients [10]. Sample preparation of urine samples is the most important aspect of data generation. Specifically, high concentrations of salts, metabolic wastes and some small molecules must be removed before analysis. Dialysis is commonly used to desalt urine samples, followed by other protein concentration methods, but requires more than 2 days. Ultracentrifugation [6] and solid phase extraction [8] are precipitation methods also used to prepare urine samples.

In this study, we used different techniques for preparation of urine samples prior to protein analysis. To prepare urine samples a PD-10 desalting column was first used to remove high concentrations of salts. This was followed by ultrafiltration or precipitation methods. Then, the prepared urine samples were examined by different analysis methods in order to (i) compare the urine preparation methods, (ii) compare the urinary protein contents from human normal and lung cancer patients, and (iii) investigate urinary protein markers of lung cancer. Thus, we present a method for urine sample preparation prior to protein analysis that allows removal of interfering compounds but retains high protein amounts. Furthermore, we found some preliminary urinary protein markers for lung cancer which may become useful markers for diagnostic and pharmaceutical applications.

\section{Materials and methods}

\subsection{Materials}

Ammonium bicarbonate, urea, CHAPS and SDS were from J. T. Baker (Phillipsburg, NJ, USA). Polycrylamide was from Amresco (Solon, OH, USA). Sodium azide and ACN were from ACROS Organics (New Jersey, USA). Acetone, chloroform and TFA were from Sigma (St. Louis, MO, USA). Methanol, chloroform and TCA were from Merck (Darmstadt, Germany). Dithioerythreitol (DTE) was from AppliChem (Darmstadt, Germany). Iodoacetamide was from Fluka (Buchs, Switzerland). Sypro Ruby was from Molecular Probes (Eugene, OR, USA). Deionized water was prepared with a tandem Milli-Q system (Millipore, Bedford, MA, USA) and used for the preparation of all buffers.

\subsection{Preparations of human urine samples}

Over $200 \mathrm{~mL}$ of clean catch first urine samples were collected in the morning from ten healthy donors and five lung cancer patients with non-small cell lung cancer (adenocarcinoma cell type, stage IV, age range 40-50 years olds). Urine samples collected in separated polypropylene tubes (NUNC, Rokilde, Denmark) containing sodium azide were stored at $-80^{\circ} \mathrm{C}$ until used. Pooled normal urine samples from ten healthy donors and pooled lung cancer urine samples from five patients were supplemented with protease inhibitor cocktail to avoid proteolysis. The samples were centrifuged at $10000 \mathrm{~g}$ for $20 \mathrm{~min}$ to remove insoluble solids. The supernatants were first passed through a PD-10 desalting column (Amersham Biosciences, Uppsala, Sweden) and eluted with $10 \mathrm{~mm}$ phosphate buffer, $\mathrm{pH}$ 7.5. The fractions containing proteins were collected and lyophilized.

\subsubsection{Ultrafiltration}

Lyophilized urine samples were resuspended in $10 \mathrm{~mm}$ phosphate buffer, pH 7.5 and loaded onto centricon $10 \mathrm{kDa}$ membrane (Millipore) in order to concentrate the proteins and remove small interference molecules. Briefly, the centricons were spun at $8000 \mathrm{~g}$, at $4^{\circ} \mathrm{C}$ for $1 \mathrm{~h}$. The same buffer was added until the conductivity of the salts in the samples was less than $100 \mathrm{mS} / \mathrm{m}$. The samples were then lyophilized.

\subsubsection{Acetone precipitation}

Lyophilized urine samples were resuspended in $10 \mathrm{~mm}$ phosphate buffer, pH 7.5 and two volumes of cold acetone was added. The mixture was stored overnight at $-20^{\circ} \mathrm{C}$ and a pellet was obtained by centrifugation at $10000 \mathrm{~g}$ at $4^{\circ} \mathrm{C}$ for $15 \mathrm{~min}$. The pellet was vacuum dried.

\subsubsection{ACN/TFA precipitation}

Lyophilized urine samples were resuspended in $10 \mathrm{~mm}$ phosphate buffer, pH 7.5 and added with two volumes of cold ACN/0.1\% TFA [11]. The mixture was vortexed and centrifuged at $10000 \mathrm{~g}$ at $4^{\circ} \mathrm{C}$ for $15 \mathrm{~min}$. The supernatant was removed and the pellet was vacuum dried.

\subsubsection{Methanol/chloroform/water precipitation}

Lyophilized urine samples were resuspended in $10 \mathrm{~mm}$ phosphate buffer, $\mathrm{pH} 7.5$ and an aliquot of urine sample $(0.1 \mathrm{~mL})$ was added to $0.4 \mathrm{~mL}$ of methanol. The mixture was vortexed and centrifuged for $10 \mathrm{~s}$ at $9000 \mathrm{~g}$. The mixture was added to $0.1 \mathrm{~mL}$ of chloroform, vortexed and centrifuged again for $10 \mathrm{~s}$ at $9000 \mathrm{~g}$. Water $(0.3 \mathrm{~mL})$ was added and the sample was vortexed vigorously and centrifuged for $1 \mathrm{~min}$ at 9000 g. The upper phase was carefully removed and discarded. A further $0.3 \mathrm{~mL}$ of methanol was added into the rest of the chloroform phase and the interphase with the precipitated protein. The sample was mixed and centrifuged again for $2 \mathrm{~min}$ at $9000 \mathrm{~g}$. The supernatant was removed and the protein pellet was vacuum dried [12].

\subsubsection{TCA/acetone precipitation}

Lyophilized urine samples were resuspended in $10 \mathrm{~mm}$ phosphate buffer, pH 7.5 and two volumes of cold 20\% TCA in acetone $\left(-20^{\circ} \mathrm{C}\right)$ was added. The mixture was stored overnight at $-20^{\circ} \mathrm{C}$ and a pellet was obtained by centrifugation at 
$10000 \mathrm{~g}, 4^{\circ} \mathrm{C}$ for $15 \mathrm{~min}$. The pellet was washed twice: first with cold acetone containing $20 \mathrm{~mm}$ DTE and then with cold acetone without DTE, and centrifuged as described above. The supernatant was removed and the pellet was vacuum dried.

\subsection{Protein analysis methods}

\subsubsection{RP-HPLC}

Analysis of pooled urine samples were performed using a reverse-phase HPLC column $(4.6 \times 250 \mathrm{~mm}$, Nucleosil 7C18) attached to a L-4250 UV-VIS detector and an L-7100 pump (all from Hitachi, Tokyo, Japan) with a $20 \mu \mathrm{L}$ sample injection loop. Two mobile phases, A (0.1\% v/v TFA, $5 \% \mathrm{v} / \mathrm{v}$ ACN) and $\mathrm{B}(0.1 \% \mathrm{v} / \mathrm{v}$ TFA, $95 \% \mathrm{v} / \mathrm{v} \mathrm{ACN})$, were used for all samples. All mobile phases were filtered ( $45 \mu \mathrm{m}$ filter for organic solvent; Millipore) and degassed by sonication (Bransonic 52; Branson, Shelton, CT, USA). All solvents were HPLC grade. Each urine sample was resuspended in mobile phase A at a concentration of $1 \mathrm{mg} / \mathrm{mL}$, filtered and injected into the HPLC column with a final volume of $10 \mu \mathrm{L}$. A linear gradient of $5 \%$ ACN to $95 \%$ ACN (0-100\% mobile phase B) was used for $25 \mathrm{~min}$ within a $30 \mathrm{~min}$ running time at a flow rate of $1 \mathrm{~mL} / \mathrm{min}$. Protein was monitored by measuring UV absorption at $280 \mathrm{~nm}$.

\subsubsection{SDS-PAGE}

Urine samples were separated under denaturing conditions in a $4-20 \%$ polyacrylamide slab gel (Invitrogen, Leek, The Netherlands). The lyophilized urine samples were resuspended in sample buffer (50 mм Tris- $\mathrm{HCl}, \mathrm{pH}$ 6.8, $0.1 \mathrm{~m}$ DTT, $10 \%$ glycerol, $2 \%$ SDS , and $0.1 \%$ bromophenol blue) at a concentration of $1 \mathrm{mg} / \mathrm{mL}$ and heated at $95^{\circ} \mathrm{C}$ for $5 \mathrm{~min}$. Each urine sample solution (10 $\mu \mathrm{g} /$ well) was separately loaded into gel wells. The SDS-PAGE gel was run in a Novex Xcell II (Novex, SanDiego, CA, USA) at $20 \mathrm{~mA}$ per gel. After completion of electrophoresis, the protein bands in the gel were visualized by Sypro Ruby staining and scanned by using a Typhoon 9200 image scanner (Amersham Biosciences). The Low Molecular Weight Calibration Kit (Amersham Biosciences) was used as standard $M_{\mathrm{r}}$ marker proteins.

\subsubsection{2-DE}

Lyophilized urine samples were dissolved in lysis buffer $(7 \mathrm{M}$ urea, 4\% CHAPS, 4 mм Tris base, 2 м Thiourea, 2\% IPG buffer $\mathrm{pH}$ 3-10 nonlinear, $65 \mathrm{~mm}$ DTE). Each sample was sonicated, centrifuged then applied onto IPG strips $(18 \mathrm{~cm}$, pH 3-10 nonlinear; Amersham Biopsciences) with a final protein concentration of $300 \mu \mathrm{g}$ in $350 \mu \mathrm{L}$ determined by the Coomassie protein assay, according to the Bradford protein dye binding assay [13]. IPGphor IEF (Amersham Biosciences) was performed under the following condition: IPG strips were rehydrated passively and/or actively for $12 \mathrm{~h}$ at
$30 \mathrm{~V}$ followed by ramping to $100 \mathrm{~V}$ for $1 \mathrm{~h}, 250 \mathrm{~V}$ for $1 \mathrm{~h}$, $500 \mathrm{~V}$ for $1 \mathrm{~h}, 1000 \mathrm{~V}$ for $1 \mathrm{~h}, 2000 \mathrm{~V}, 1 \mathrm{~h}$, and focusing at $6000 \mathrm{~V}$ for up to $50000 \mathrm{Vh}$. After IEF, the IPG strips were equilibrated in equilibration buffer 1 (50 mm Tris- $\mathrm{HCl}$, pH 8.8, 6 м urea, 30\% v/v glycerol, 2\% w/v SDS, 2\% w/v DTE and a trace of bromophenol blue) for $15 \mathrm{~min}$, and then subsequently alkylated in buffer $2(50 \mathrm{~mm}$ Tris- $\mathrm{HCl} \mathrm{pH} 8.8,6 \mathrm{~m}$ urea, $30 \% \mathrm{v} / \mathrm{v}$ glycerol, $2 \% \mathrm{w} / \mathrm{v}$ SDS, $2.5 \% \mathrm{w} / \mathrm{v}$ iodoacetamide and a trace of bromophenol blue) for $15 \mathrm{~min}$. Each equilibrated IPG strip was placed on top of the $15 \%$ polyacrylamide gel $(18 \times 18 \mathrm{~cm})$ and covered with $0.5 \%$ agarose. The second-dimensional separation was carried out at $40 \mathrm{~mA}$ per gel at $15^{\circ} \mathrm{C}$ until the bromophenol blue dye front reached the bottom of the gel. At the end of each run, the 2-D gels were stained with Sypro Ruby and scanned using a Typhoon 9200 image scanner (Amersham Biosciences). In addition, the 2-D gel images were exported to the image analysis software program, PDQuest 2-D analysis software version 7.1.1 (Bio-Rad, Hercules, CA, USA).

\subsubsection{Protein digestion}

Protein spots were manually excised from the gels and transferred to $500 \mu \mathrm{L}$ siliconized Eppendorfs. The gel pieces were washed twice with $200 \mu \mathrm{L}$ of $50 \%$ ACN/25 mM ammonium bicarbonate buffer, $\mathrm{pH} 8.0$, for $15 \mathrm{~min}$ each. The gel pieces were then washed once with $200 \mu \mathrm{L}$ of $100 \%$ ACN and dried using a Speed-Vacuum concentrator. Dried gel pieces were swollen in $10 \mu \mathrm{L}$ of $25 \mathrm{~mm}$ ammonium bicarbonate containing $0.1 \mu \mathrm{g}$ trypsin; (sequencing grade; Promega, Madison, WI, USA). Gel pieces were then crushed with a siliconized blue stick and incubated at $37^{\circ} \mathrm{C}$ for at least $16 \mathrm{~h}$. Peptides were subsequently extracted twice with $50 \mu \mathrm{L}$ of $50 \%$ ACN $/ 5 \%$ TFA, then the extracted solutions were combined and dried using a SpeedVac concentrator. The peptides or pellets were then resuspended in $10 \mu \mathrm{L}$ of $0.1 \%$ TFA and the suspended solutions were purified using ZipTip C18 (Millipore). Ten microlitres of sample was drawn up and down in the ZipTip 10 times and the ZipTip was washed with $10 \mu \mathrm{L}$ of $0.1 \%$ formic acid by drawing up and expelling the washing solution three times. The peptides were eluted with $5 \mu \mathrm{L}$ of $75 \% \mathrm{ACN} / 0.1 \%$ formic acid.

\subsubsection{MALDI-MS and MS/MS analysis}

For MALDI MS and MS/MS analysis, the samples were premixed in a ratio of $1: 1$ with matrix solution $(5 \mathrm{mg} / \mathrm{mL}$ CHCA in $50 \% \mathrm{ACN}, 0.1 \% \mathrm{v} / \mathrm{v}$ TFA and $2 \% \mathrm{w} / \mathrm{v}$ ammonium citrate) and spotted onto the 96-wells format MALDI sample stage. Data was directed acquisition on the Q-TOF Ultima MALDI instrument which was fully automated with predefined probe motion pattern and the peak intensity threshold for switching over from MS survey scanning to MS/MS, and from one MS/MS to another. Within each well, as many parent ions meeting the predefined criteria (any peak within the $m / z$ 800-3000 range with intensity above 10 count 


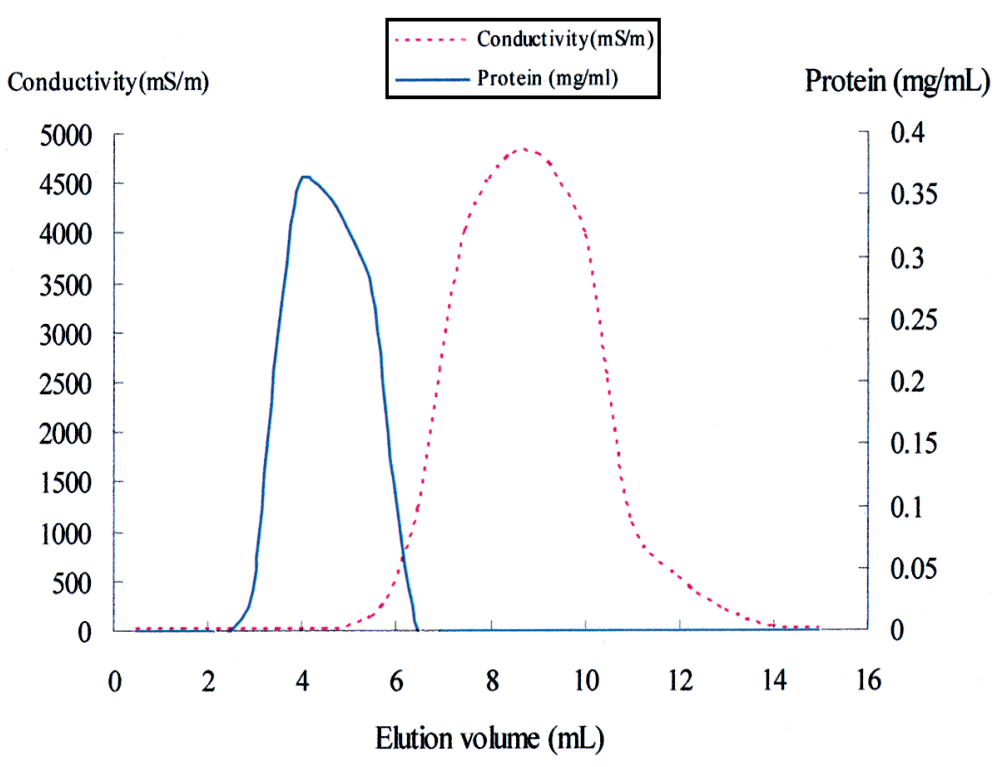

different sample preparations to prepare urine samples, which were pooled together to reduce variation of individual samples and composition, prior to analysis. First, the high abundance of interfering molecules containing salts, electrolytes and/or some nitrogenous waste products in urine samples were removed by Sephadex gel filtration using a PD-10 desalting column (Fig. 1) because they could negatively affect further proteomic analysis. Although the major urinary proteins were distinctly separated from small interferences in the elution volume of 3-6 $\mathrm{mL}$, the urine samples still contained some salts from the elution buffer and some interfering substances. However, the first step of urine sample preparation by gel filtration removed most of the salts and other electrolytes from the urine samples. After that, the proteins in the urine samples were concentrated and the remaining salts and some nitrogenous waste products were removed by various preparation methods in order to reduce interfering molecules for further analysis, especially in the first dimension of 2-DE. Ultrafiltration and four precipitation methods were compared to find the best sample preparation of urine samples for investigating urinary protein markers in lung cancer by high-throughput analysis techniques.

\subsection{RP-HPLC analysis}

The components in urine samples from normal and lung cancer patients prepared by different preparation methods were separated by RP-HPLC and demonstrated different chromatogram profiles (Fig. 2). RP-HPLC chromatograms from all prepared urine samples showed a major protein peak in an elution range of $40-80 \% \mathrm{ACN}$, indicating that the urine components are dependent on hydrophobic properties. Sample preparations of normal urine and lung cancer urine by ultrafiltration, acetone precipitation and ACN/TFA precipitation showed similar profiles (Fig. 2: A13, B1-3). In contrast, samples prepared by methanol/ chloroform/water and TCA in acetone precipitations showed less protein components and some peaks disappeared (Fig. 2: A4-5, B4-5). In addition, the chromatogram profiles of normal and lung cancer urines prepared by each preparation method were compared by superimposing the traces and showed distinct differences in protein components, especially at $40-80 \%$ ACN elution (Fig. 2, C1-C5). By this analysis, we found that different sample preparation methods for urine samples provided different protein profiles. Moreover, RP-HPLC analysis tended to high light different urinary proteins between normal and lung cancer that may be biomarkers of lung cancer disease. 


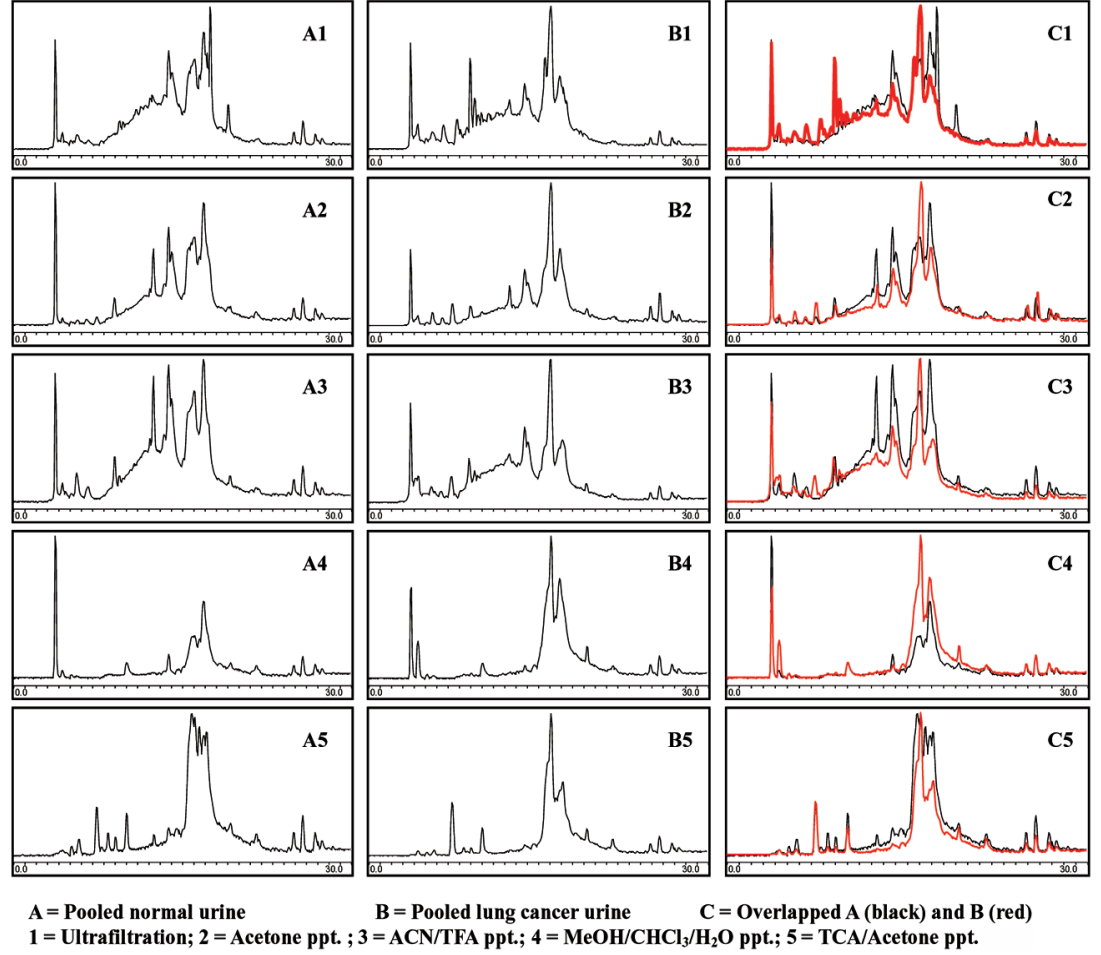

\subsection{2-DE analysis}

The 2-DE images of normal and lung cancer urine samples prepared by different preparation methods are demonstrated in Fig. 4. The 2-DE image of urine samples prepared by ultrafiltration showed the highest protein spots both in normal and lung cancer patient samples compared to theirs images resulting from precipitations methods. One factor that influences separation by 2-DE analysis is the conductivity of the samples. Each preparation method gave different conductivities as shown in Table 1. TCA precipitation provided the lowest conductivity and ultrafiltration was manually controlled for removing salts. However, the effect of salts on 2-DE is reduced when the conductivity of samples is lower than $200 \mathrm{mS} / \mathrm{m}$ (20 $\mathrm{mm} \mathrm{NaCl}$ ) or when using IEF paper (Amersham Biosciences) to absorb excess salts. Using precipita-

Figure 2. RP-HPLC chromatograms of pooled normal (A) and lung cancer (B) urine samples preparing by ultrafiltration, acetone precipitation, ACN/TFA precipitation, methanol/chloroform/ water precipitation and TCA in acetone precipitation. The overlapped chromatogram profiles of urine samples (black line) from normal and lung cancer (red line) patients is shown in (C). The samples were analyzed on a Nucleosil 7C18, $4.6 \times 250 \mathrm{~mm}$ column using a linear gradient of $0-100 \%$ mobile phase B at a flow rate of $1 \mathrm{~mL} / \mathrm{min}$ for $25 \mathrm{~min}$ and washed with $100 \%$ mobile phase $B$ until the running time reached $30 \mathrm{~min}$. Mobile phase $A$ was $5 \%$ $\mathrm{v} / \mathrm{v}$ ACN, $0.1 \% \mathrm{v} / \mathrm{v}$ TFA and mobile phase $\mathrm{B}$ was $95 \% \mathrm{v} / \mathrm{v} \mathrm{ACN}$, $0.1 \% \mathrm{v} / \mathrm{v}$ TFA. Protein elution was monitored at $280 \mathrm{~nm}$ absorbance. 1 , ultrafiltration; 2 , acetone precipitation; 3 , ACN/TFA precipitation; 4, methanol/chloroform/water precipitation; 5, TCA/ acetone precipitation.

\subsection{SDS-PAGE analysis}

A SDS-PAGE gel of urine samples showed no differences in protein patterns for each sample preparation method but showed the different protein patterns between normal and lung cancer urines (Fig. 3). The major differences between lung cancer urine samples compared to normal urine samples were observed at $14 \mathrm{kDa}$ and in the range of 28 to $42 \mathrm{kDa}$ where protein bands with higher intensity than in normal urine samples were found. In addition, lung cancer urine samples had less protein at $50 \mathrm{kDa}$ than normal urine samples. Although SDS-PAGE could not show the major differences between sample preparations because of limited separation in one dimension, it showed some different protein bands between normal and lung cancer disease. tion methods, some protein spots were lost and the protein spots on 2-D gels were poorly focused, especially at the $M_{\mathrm{r}}$ ranger lower than $30 \mathrm{kDa}$. Urine samples from normal and lung cancer patients prepared by methanol/chloroform/ water precipitation had the lowest amount of protein in the low $M_{\mathrm{r}}$ range, but had many protein spots in the $M_{\mathrm{r}}$ range higher than $60 \mathrm{kDa}$ (Fig. 4: A4, B4). Using the ultrafiltration

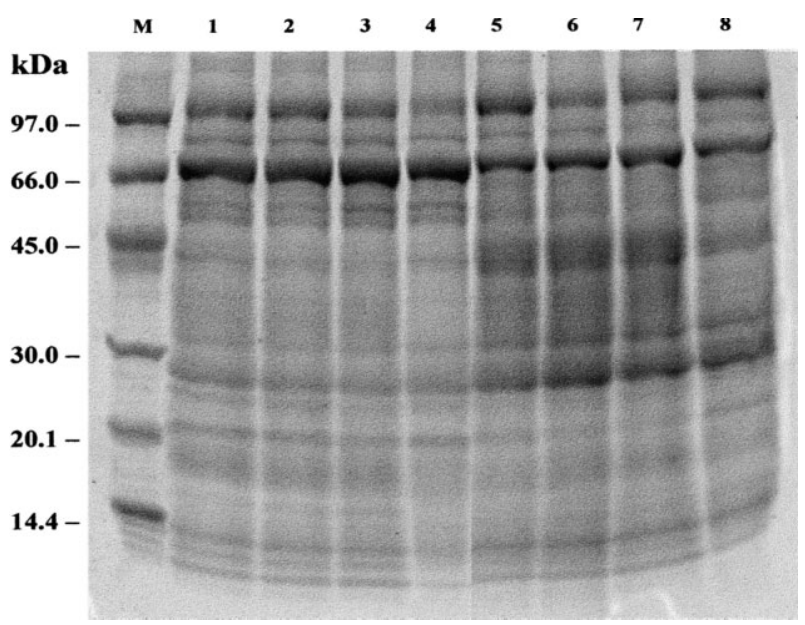

Figure 3. SDS-PAGE of pooled urine samples from normal and lung cancer patients. SDS-PAGE was carried out on a mini $4-20 \%$ gradient gel with $10 \mu \mathrm{g}$ protein/well. Lane $\mathrm{M}$ is the protein standard markers, lanes 1-4 are pooled normal urine samples prepared using ultrafiltration, acetone precipitation, ACN/TFA precipitation and methanol/chloroform/water precipitation, respectively. Lanes 5-8 are pooled lung cancer urine samples prepared by using ultrafiltration, acetone precipitation, ACN/TFA precipitation and methanol/chloroform/water precipitation, respectively. 

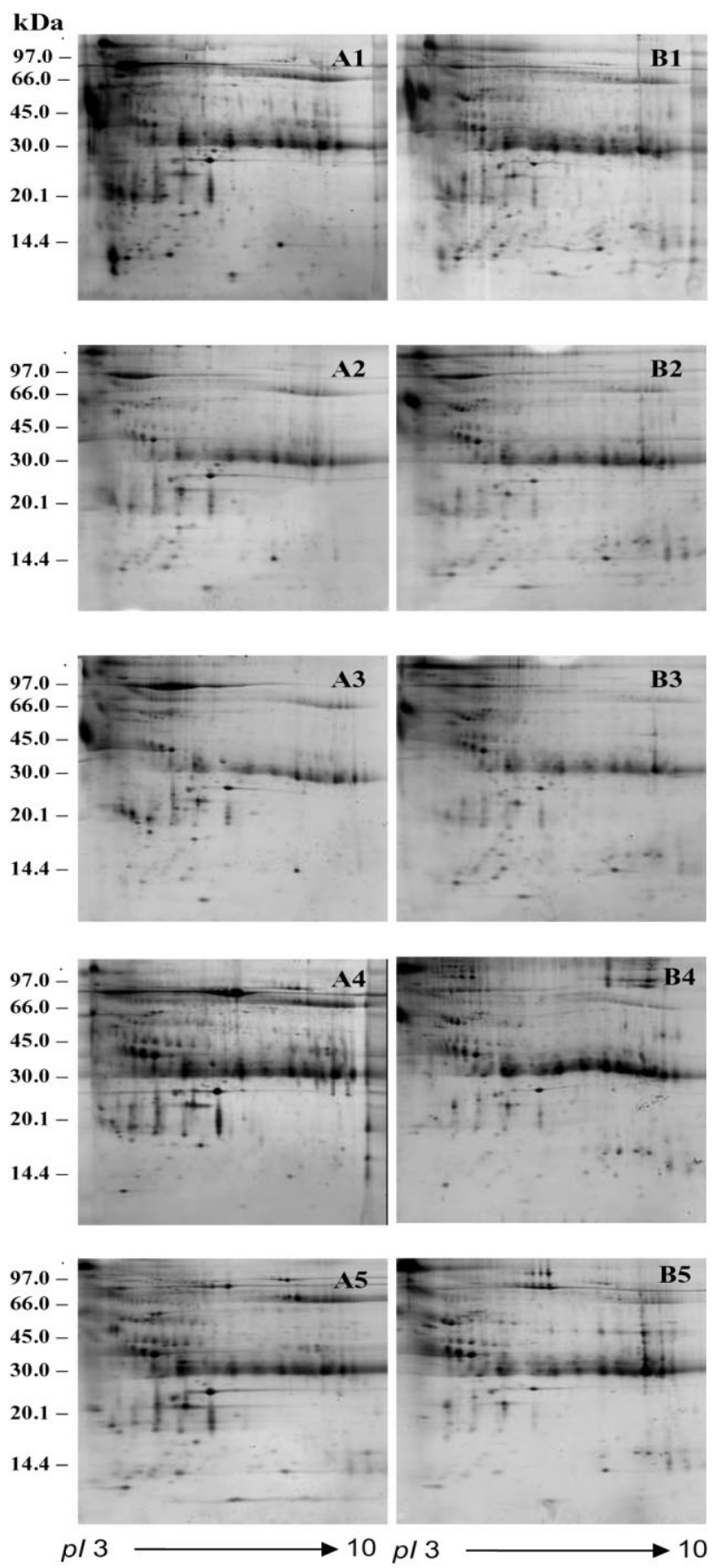

Figure 4. 2-DE gel images of pooled normal urine samples $(A)$ and lung cancer urine pooled samples (B), prepared by different methods. Gels A1 and B1 represent urine samples prepared using ultrafiltration of pooled normal and lung cancer patients, respectively. Gels A2 and B2 represent urine samples prepared using acetone precipitation of pooled normal and lung cancer patients, respectively. Gels A3 and B3 represent urine samples prepared using ACN/TFA precipitation of pooled normal and lung cancer patients, respectively. Gels A4 and B4 represent urine samples prepared using methanol/chloroform/water precipitation of pooled normal and lung cancer patients, respectively. Gels A5 and B5 represent urine samples prepared using TCA in acetone precipitation of pooled normal and lung cancer patients, respectively.
Table 1. Summary of preparation methods for urine samples from normal and lung cancer patients

\begin{tabular}{llll}
\hline $\begin{array}{l}\text { Sample preparation } \\
\text { methods }\end{array}$ & $\begin{array}{l}\text { Conductivity } \\
(\mathrm{mS} / \mathrm{m})\end{array}$ & \multicolumn{2}{c}{$\begin{array}{l}\text { Protein spots on 2-D } \\
\text { gel image }\end{array}$} \\
\cline { 3 - 4 } & & $\begin{array}{l}\text { Normal } \\
\text { urine }\end{array}$ & $\begin{array}{l}\text { Lung cancer } \\
\text { urine }\end{array}$ \\
\hline Ultrafiltration & $<100 \mathrm{mS} / \mathrm{m}$ & 829 & 827 \\
$\begin{array}{l}\text { Acetone precipitation } \\
\begin{array}{l}\text { ACN/TFA precipitation } \\
\text { Methanol/chloroform/water } \\
\text { precipitation }\end{array}\end{array}$ & $>100 \mathrm{mS} / \mathrm{m}$ & 467 & 547 \\
$\begin{array}{l}\text { TCA/Acetone precipitation } \\
\text { ren }\end{array}$ & $>100 \mathrm{mS} / \mathrm{m}$ & 393 & 458 \\
\hline
\end{tabular}

The conductivity of each sample was detected followed by analysis with 2-DE which detected the quantity of protein spots by PDQuest 2-D analysis software, version 7.1.1 (Bio-Rad).

method allowed most protein components in urine samples to be visualized on 2-D gels with good separation and higher protein intensity than precipitation methods which have denaturing conditions due to the organic solvents used. Although organic solvents, such as acetone, methanol and ethanol can easily precipitate the hydrophilic proteins, hydrophobic proteins tend to remain soluble in the aqueous fraction [16]. In addition, some urinary proteins have high solubility in solution according to the source of the urine sample that most of the proteins dissolved in water; therefore, some proteins are difficult to precipitate by organic solvent.

Furthermore, the quantity of urinary protein spots between normal and lung cancer urines were analyzed by PDQuest 2-D analysis software version 7.1.1. The total number of spots detected is shown in Table 1. Both urine samples of normal and lung cancer patients prepared by ultrafiltration showed the highest number of protein spots on 2-D gel images while the urine samples prepared by ACN/TFA precipitation showed the lowest. In contrast, the number of urinary protein spots on 2-D gels detected in our work was higher than those obtained in previous research in which urine samples were prepared by acetone precipitation and ultracentrifugation [6], solid-phase extraction [8], and dialysis followed by ultrafiltration [9]; except for the work of Pieper et al. [7] who reported a similar protein separation profile. The above reports used only one or a few methods of urine preparation for urinary protein analysis. Their protein analysis results showed poor protein resolution in separations. Thus, we compared sample preparations of urine samples and showed the importance of good sample preparation for subsequent protein analysis. Moreover, we used the selective preparation for investigating some urinary protein markers in lung cancer disease. The PDQuest software was also used to compare the protein patterns of urine samples in both normal and lung cancer patients (Fig. 5). According to the result above, we chose 2-D gel images of 


\section{kDa}
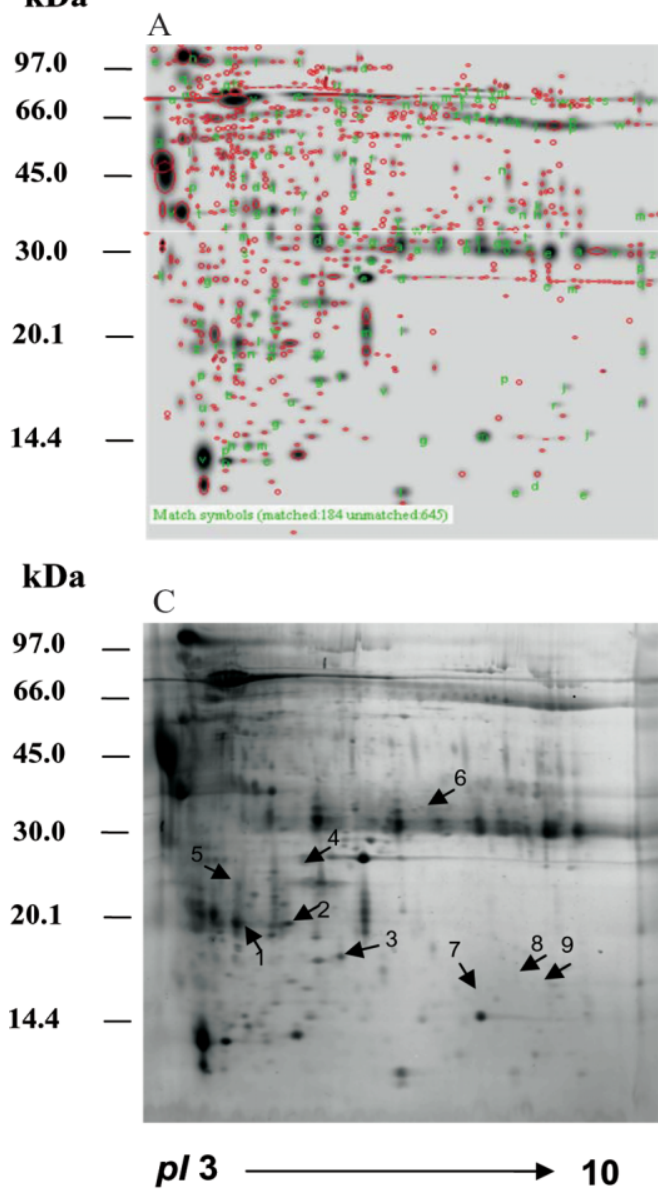

B

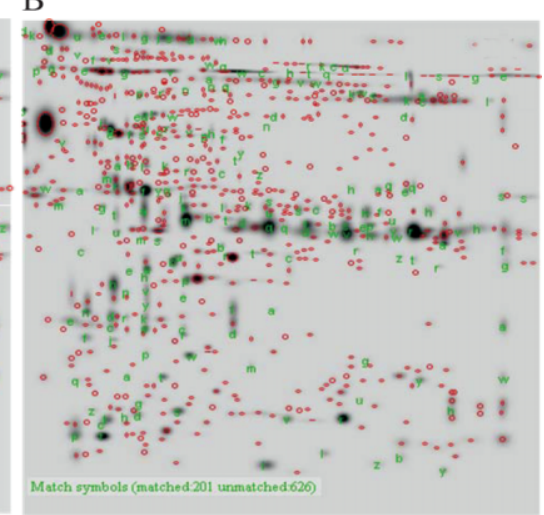

D

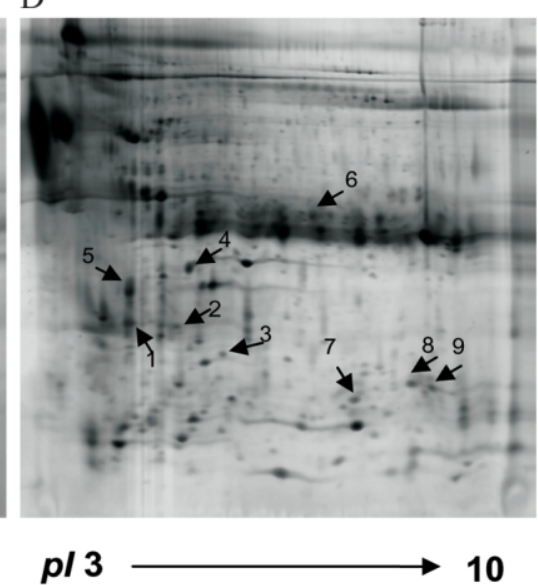

Figure 5. Comparison of 2-D gel images of pooled normal and lung cancer urine samples prepared by ultrafiltration and analyzed with PDQuest 2-D software version 7.1.1. Gels: (A) normal urine as the reference gel compared to lung cancer urine. (B) lung cancer urine as the reference compared to normal urine. (C) Normal urinary proteins. (D) Lung cancer urinary proteins. Green labeled spots represent matched spots and red labeled spots represent unmatched spots. The black arrows show proteins that were excised and analyzed by MALDI Q-TOF MS. normal and lung cancer urine samples sequentially prepared by gel filtration and ultrafiltration to compare protein patterns and identify proteins because this preparation gave a good separation on 2-DE and provided the highest number of protein spots. The majority of differentially expressed proteins were in the $M_{\mathrm{r}}$ range below $30 \mathrm{kDa}$ which was similar to the results from SDS-PAGE. Nine spots showing differential expression in both normal and lung cancer were excised from gels, digested with trypsin and identified by MALDI QTOF MS or MS/MS analysis.

\subsection{Protein identification}

Nine major protein spots on 2-D gels were analyzed by MALDI-TOF-MS or MS/MS and used in searches for matching proteins and their functions (Table 2 and Table 3). All recognized protein spots in the 2-D gel were identified by PMF. In all cases, the spots were sequentially subjected to MS/ MS sequencing to identify the proteins. We found that there were three down-regulated proteins and six up-regulated proteins, related to lung cancer disease. The down-regulated proteins are CD59 glycoprotein precursor, activator of cAMP- responsive element modulator and transthyretin (TTR). CD59 is down-regulated in lung cancer urine, which is functionally associated with natural cytotoxicity receptors and activates human NK cell-mediated cytotoxicity [23]. It has been reported that losing CD59 expression in breast tumors correlates with poor survival and may offer a selective advantage for breast cancers, resulting in more aggressive tumors and conferring a poor prognosis for patients [24]. Another protein that showed down-regulation in lung cancer urine was TTR. About $40 \%$ of plasma TTR circulates in a tight protein-protein complex with the plasma retinol-binding protein (RBP), which was found to be up-regulated. The formation of a complex with RBP stabilizes the binding of retinol to RBP and decreases the glomerular filtration and renal catabolism of the relatively small RBP molecule [25]. Up-regulated proteins detected are plasma RBP, GM2 activator protein (GM2AP), Ig lambda light chain and Ig kappa chain C regions. Plasma RBP is up-regulated in lung cancer urine, first may be caused of low TTR affected to loss of RBP into urine and the second, RBP concentration is significantly higher in neoplastic tissue may secrete excess RBP from tumor tissue more than the amount of TTR for binding, finally it passes into the urine [26, 27]. 
Table 2. Protein identification of urinary protein markers in lung cancer urine by MALDI-TOF-MS/MS based on the Swiss-Prot database

\begin{tabular}{|c|c|c|c|c|c|c|c|}
\hline $\begin{array}{l}\text { Spot } \\
\text { no. }\end{array}$ & Protein name & $\begin{array}{l}\text { Acc. } \\
\text { No. }\end{array}$ & $\begin{array}{l}\text { Theo. } M_{\mathrm{r}} \\
(\mathrm{kDa}) / \mathrm{p} /\end{array}$ & $\begin{array}{l}\text { App. } M_{\mathrm{r}} \\
(\mathrm{kDa}) / \mathrm{p} /\end{array}$ & $\begin{array}{l}\text { Queries } \\
\text { matched }\end{array}$ & $\begin{array}{l}\text { Seq. cov. } \\
(\%)\end{array}$ & Matched sequences \\
\hline 1 & $\begin{array}{l}\text { CD59 } \\
\text { glycoprotein } \\
\text { [precursor] }\end{array}$ & $\underline{\mathrm{P} 13987}$ & $14.1 / 6.0$ & $20 / 4.3$ & 1 & 9 & LRENELTYYCCK \\
\hline 2 & $\begin{array}{l}\text { Activator of cAMP- } \\
\text { responsive element } \\
\text { modulator, testis - } \\
\text { human }\end{array}$ & Q8WW21 & $32.8 / 8.0$ & $20 / 4.8$ & 24 & 73 & $\begin{array}{l}\text { MTTAHFYCOYCTASLLGKK } \\
\text { MTTAHFYCOYCTASLLGKK } \\
\text { TTAHFYCOYCTASLLGKK } \\
\text { DFCYKVR } \\
\text { VRHWHEGCFK } \\
\text { HWHEGCFKCTK } \\
\text { CTKCNHSLVEKPFAAK } \\
\text { DERLLCTECYSNECSSK } \\
\text { LLCTECYSNECSSK } \\
\text { MEFKGNYWHETCFVCENCR } \\
\text { OPIGTKPLISKESGNYCVPCFEK } \\
\text { ESGNYCVPCFEKEFAHYCNFCK } \\
\text { EFAHYCNFCKK } \\
\text { VITSGGTTFCDQLWHK } \\
\text { KDLCEEOFMSR } \\
\text { CVACSKPISGLTGAK } \\
\text { FICFODSOWHSECFNCGR } \\
\text { FICFODSOWHSECFNCGR } \\
\text { FICFODSOWHSECFNCGRCSVSL } \\
\text { VGK } \\
\text { CSVSLVGKGFLTONK } \\
\text { GFLTONKEIFCOK } \\
\text { EIFCOK } \\
\text { EIFCOKCSSGMDTDI } \\
\text { CSSGMDTDI }\end{array}$ \\
\hline 3 & $\begin{array}{l}\text { Transthyretin (prealbumin, } \\
\text { amyloidosis type I) }\end{array}$ & $\underline{\mathrm{P} 02766}$ & $15.9 / 5.5$ & $18 / 5.3$ & 1 & 9 & GSPAINVAVHVFRK \\
\hline 4 & $\begin{array}{l}\text { Plasma retinol-binding } \\
\text { protein [Precursor] }\end{array}$ & $\underline{P 02753}$ & $23.0 / 5.8$ & $25 / 5.2$ & 2 & 19 & $\begin{array}{l}\text { GNDDHWIVDTDYDTYAVOYSCR } \\
\text { LLNLDGTCADSYSFVFSR }\end{array}$ \\
\hline 5 & $\mathrm{G}(\mathrm{M} 2)$ activator protein & $\underline{P 17900}$ & $20.8 / 5.2$ & $23 / 4.3$ & 1 & 10 & SEFVVPDLELPSWLTTGNYR \\
\hline 6 & Ig lambda light chain & $\underline{\mathrm{P} 01842}$ & $11.2 / 6.8$ & $31 / 5.8$ & 2 & 32 & $\begin{array}{l}\text { AAPSVTLFPPSSEELQANK } \\
\text { YAASSYLSLTPEOWK }\end{array}$ \\
\hline 7 & Ig kappa chain $\mathrm{C}$ region & $\underline{\mathrm{P} 01834}$ & 11.6/5.6 & $16 / 7.2$ & 2 & 32 & $\begin{array}{l}\text { TVAAPSVFIFPPSDEQLK } \\
\text { SGTASVVCLLNNFYPR }\end{array}$ \\
\hline 8 & Ig kappa chain $\mathrm{C}$ region & $\underline{\mathrm{P} 01834}$ & $11.0 / 5.6$ & $16 / 6.9$ & 1 & 16 & SGTASVVCLLNNFYPR \\
\hline 9 & Ig kappa chain $\mathrm{C}$ region & P01834 & $11.6 / 5.6$ & $15 / 6.2$ & 2 & 32 & $\begin{array}{l}\text { TVAAPSVFIFPPSDEQLK } \\
\text { SGTASVVCLLNNFYPR }\end{array}$ \\
\hline
\end{tabular}

GM2AP was up-regulated and showed high expression in lung cancer urine. It is an essential cofactor for the degradation of ganglioside GM2 to GM3 by lysosomal $\beta$-hexminidase $\mathrm{A}$ and is also related to the changing level of ganglioside. Tumor-associated gangliosides may play a role in cancer progression [21, 28]. Tumor cells are synthesized and shed gangliosides into their microenvironments leading to elevated levels of tumor-associated gangliosides in the serum $[29,30]$. Changes in the amounts of gangliosides in serum can influence the rate of tumor growth through an unde- termined mechanism [31]. High expression of Ig light chains was also found in lung cancer urine samples. There are some reports that Ig light chain may protect against a diseased state; plasma cells are capable of presenting antigenic determinants derived from a secreted monoclonal light chain in an MHC class I context, and of predominantly inducing a monoclonal Ig-specific T-cell response which can contribute to tumor rejection [32]. Ig free light chains can also be transfered immediately to hypersensitivity-like responses in mice and may contribute to the mechanism by which mast cells 
Table 3. Protein and gene identification, spot quantity ratio/regulation and description of urinary protein markers in lung cancer urines

\begin{tabular}{|c|c|c|c|c|}
\hline $\begin{array}{l}\text { Spot } \\
\text { no. }\end{array}$ & Protein name & $\begin{array}{l}\text { Gene } \\
\text { name }\end{array}$ & $\begin{array}{l}\text { Quantity ratio } \\
\text { (normal/lung)/ } \\
\text { Regulation }\end{array}$ & Description \\
\hline 1 & $\begin{array}{l}\text { CD59 glycoprotein precursor } \\
\text { (Membrane attack complex } \\
\text { inhibition factor) (MACIF), } \\
\text { CD59_HUMAN }\end{array}$ & CD59 & 4.60/Down & $\begin{array}{l}\text { Small glycoproteins found on both hematopoietic and } \\
\text { nonhematopoietic cells. CD59 restricts the cytolytic } \\
\text { activity of homologous complement by binding to C8 } \\
\text { and C9 and blocking the assembly of the membrane } \\
\text { attack complex. }[17,18] \text {. }\end{array}$ \\
\hline 2 & $\begin{array}{l}\text { Activator of cAMP-responsive } \\
\text { element modulator, testis - } \\
\text { human }\end{array}$ & none & 5.06/Down & $\begin{array}{l}\text { CREM modulates the transcription of several genes } \\
\text { containing a cAMP responsive element motif in their } \\
\text { promoter region. Alternative splicing of the CREM } \\
\text { gene generates both activator and repressor isoforms } \\
\text { that are expressed in a tissue and cell specific manner } \\
{[19,20] \text {. }}\end{array}$ \\
\hline 3 & $\begin{array}{l}\text { Transthyretin (prealbumin, } \\
\text { amyloidosis type I), } \\
\text { TTHY_HUMAN }\end{array}$ & $\begin{array}{l}\text { TTR } \\
\text { or PALB }\end{array}$ & 6.30/Down & $\begin{array}{l}\text { A homotetrameric thyroid-hormone transporting pro- } \\
\text { tein [21]. About } 40 \% \text { of plasma transthyretin circu- } \\
\text { lates in a tight protein-protein complex with the } \\
\text { plasma retinol-binding protein (RBP). Defects in TTR } \\
\text { are a cause of amyloidosis. Distinct forms of amyloi- } \\
\text { dosis have been related to different point mutations. }\end{array}$ \\
\hline 4 & $\begin{array}{l}\text { Plasma retinol-binding protein } \\
\text { [Precursor], RETB_HUMAN }\end{array}$ & RBP4 & $0.06 / U p$ & $\begin{array}{l}\text { Delivers retinol from the liver stores to the peripheral } \\
\text { tissues. In plasma, the RBP-retinol complex interacts } \\
\text { with transthyretin which prevents its loss by filtration } \\
\text { through the kidney glomerulus's. }\end{array}$ \\
\hline 5 & $\begin{array}{l}\text { G(M2) activator protein, } \\
\text { SAP3_HUMAN }\end{array}$ & GM2A & $0.07 / \mathrm{up}$ & $\begin{array}{l}\text { The GM2 activator protein is a small monomeric protein } \\
\text { containing a single site for Asn-linked glycosylation. } \\
\text { Its only proven in vivo function is to act as a substrate } \\
\text { specific cofactor for the hydrolysis of GM2 gan- } \\
\text { glioside by lysosomal beta-hexosaminidase A [22]. }\end{array}$ \\
\hline 6 & $\begin{array}{l}\text { Ig lambda light chain, } \\
\text { LAC_HUMAN }\end{array}$ & IGLC1 & $0.74 / \mathrm{up}$ & \multirow{4}{*}{$\begin{array}{l}\text { High levels of monoclonal IgG (less commonly IgA, } \\
\text { rarely lgD or IgE) in the serum and free light chains of } \\
\text { the same kappa or lambda type in the urine (Bence- } \\
\text { Jones proteinuria) is a hallmark of myeloma disease. } \\
\text { Overall, about } 70 \% \text { of myeloma patients have both } \\
\text { serum monoclonal lg and urinary lg light chains, and } \\
\text { the remaining patients have urinary lg light chains } \\
\text { alone without serum monoclonal lg. }\end{array}$} \\
\hline 7 & $\begin{array}{l}\text { Ig kappa chain C region, } \\
\text { KAC_HUMAN }\end{array}$ & IGKC & 0/Up & \\
\hline 8 & $\begin{array}{l}\text { Ig kappa chain C region, } \\
\text { KAC_HUMAN }\end{array}$ & IGKC & $0 / \cup p$ & \\
\hline 9 & $\begin{array}{l}\text { Ig kappa chain C region, } \\
\text { KAC_HUMAN }\end{array}$ & IGKC & $0 / \mathrm{p}$ & \\
\hline
\end{tabular}

The spot quantity ratio is defined as up- and down-regulation of expressed protein depending on protein spot intensity.

regulate immune diseases [33]. Light chain gene expression, neoplastic and autoimmune disease are being studied to understand the pathways. These identified proteins may become more interesting for diagnostic purposes if their upregulation can be confirmed by immunohistochemistry or other specific techniques in further analysis.

We examined preparation methods for urine samples from pooled normal and lung cancer patients by proteomic analysis and found the best preparation method for urine samples. According to the results, we chose the sequential preparation of urine samples by gel filtration and ultrafiltration as the selective preparation method to allow preliminarily investigation of urinary protein markers in lung cancer disease. Nevertheless, there are many points that must be considered in the investigation of urinary biomarkers. One is the number of patients and healthy donors available for pooling urine samples. We used five lung cancer patients diagnosed with the same specific cell type and stage for preliminary examination and found the proper sample preparation method. Since proteins in human urine can be affected by many factors such as age, gender, chemotherapy treatment, nutrition and metastasis of malignant tissues, the accuracy of biomarker identification must be concerned with using an adequate sample size of cancer patients to account for these effects. When using samples from large numbers of cancer patients and healthy controls, pooling urine sam- 
ples is a suitable way for analysis which can reduce time, cost and allows quick interpretation of data. However, these classified criteria need time and man power for collecting and preparing urine samples. The sample preparation of urine samples, protein patterns, protein identifications and identification of differentially expressed proteins are very important and useful for further studies on the proteome of lung cancer urines. The resulting information is potentially useful for pharmaceutical applications, for example, the preparation of a protein chip of lung cancer urines for clinical diagnosis.

\section{Concluding remarks}

In this study, we successfully pooled examined preparation methods of pooled normal and lung cancer urines for analysis of urinary proteins and identified some preliminary differentially expressed protein markers. Although the results of HPLC and SDS-PAGE showed few differences in protein patterns between normal and lung cancer urines prepared by the sample preparation, methods compared 2-DE results gave more useful information of different protein patterns related to sample preparations and urine sources between normal and lung cancer patients. We found that the sequential preparation method of urine samples by gel filtration and ultrafiltration provided the largest protein quantity in normal and lung cancer urines, compared to precipitation methods. By proteomic analysis, we compared the protein patterns between normal and lung cancer urines, and found some interesting proteins such as CD59 glycoprotein, TTR, GM2AP and Ig-free light chain to be differentially expressed. These urinary biomarkers may be useful as lung cancer markers, which are needed for further preclinical diagnostic and therapeutically applications.

This research is part of the Royal Golden Jubilee Ph. D. project from Mr. Payungsak Tantipaiboonwong supported by the Thailand Research Fund (Bangkok, Thailand). This work is also supported by the Graduate School, Chiang Mai University (Chiang Mai, Thailand). We gratefully acknowledge the provision of urine samples from Lampang Regional Cancer Center (Thailand). We thank the Core Facilities for Proteomics Research, Academia Sinica, Taiwan, for their support with the proteomics experiments.

\section{References}

[1] Xu, G., Stefano, C. D., Liebich, H. M., Zhang, Y., Lu, P., J. Chromatogr. B. 1999, 732, 307-313.

[2] Yang, J., Xu, G., Kong, H., Zheng, Y. et al., J. Chromatogr. B. 2002, 780, 27-33.

[3] Liebich, H. M., Xu, G., Stefano, C. D., Lehmann, R., J. Chromatogr. A. 1998, 793, 341-347.
[4] Carter, S. J., Li, X. F., Mackey, J. R., Modi, S. et al., Electrophoresis 2001, 22, 2730-2736.

[5] Spahr, C. S., Davis, M. T., McGinley, M. D., Robinson, J. H. et al., Proteomics 2001, 1, 93-107.

[6] Thongboonkerd, V., McLeish, K. R., Arthur, J. M., Klein, J. B., Kidney Int. 2002, 62, 1461-1469.

[7] Pieper, R., Gatlin, C. L., McGrath, A. M., Makusky, A. J. et al., Proteomics 2004, 4, 1159-1174.

[8] Pang, J. X., Ginanni, N., Dongre, A. R., Hefta, S. A., Opiteck, G. J., J. Proteome Res. 2002, 1, 161-169.

[9] Lafitte, D., Dussol, B., Anderson, S., Vazi, A. et al., Clin. Biochem. 2002, 35, 581-589.

[10] Østergaard, M., Wolf, H., Ørntoft, T. F., Celis, J. E., Electrophoresis 1999, 20, 349-354.

[11] Chertov, O., Biragyn, A., Kwak, L. W., Simpson, J. T. et al., Proteomics 2004, 4, 1195-1203.

[12] Wessel, D., Flugge, U. I., Anal. Biochem. 1984, 138, 141-143.

[13] Bradford, M., Anal. Biochem. 1976, 72, 248-254.

[14] Anderson, N. G., Anderson, N. L., Tollaksen, S. L., Clin. Chem. 1979, 25, 1199-1210.

[15] Beetham, R., Cattell, W. R., Ann. Clin. Biochem. 1993, 30, 425-434.

[16] Srivastava, O. P., Srivastava, K., Curr. Eye Res. 1998, 17, 1074-1081.

[17] Barclay, A. N., Brown, M. H., Law, S. K. A., McKnight, A. J. et al., in: The Leucocyte Antigen FactsBook, Academic Press, London, England 1997, pp. 290-291.

[18] Rollins, S. A., Zhao, J. I., Ninomiya, H., Sims, P. J., Immunology 1991, 146, 2345-2351.

[19] Foulkes, N. S., Borrelli, E., Sassone-Corsi, P., Cell 1991, 64, 739-749.

[20] Laoide, B. M., Foulkes, N. S., Schlotter, F., Sassone-Corsi, P., EMBO J. 1993, 12, 1179-1191.

[21] Peterson, P. A., J. Biol. Chem. 1971, 246, 34-43.

[22] Meier, E. M., Schwarzmann, G., Furst, W., Sandhoff, K., J. Biol. Chem. 1991, 266, 1879-1887.

[23] Marcenaro, E., Augugliaro, R., Falco, M., Castriconi, R. et al, Eur. J. Immunol. 2003, 33, 3367-3376.

[24] Madjd, Z., Pinder, S. E., Paish, C., Ellis, I. O. et al., J. Patho. 2003, 200, 633-639.

[25] Naylor, H. M., Newcomer, M. E., Biochemistry 1999, 38, 2647-2653.

[26] Fex, G., Linell, F., Ljunoberg, O., Breast Cancer Res. Treat. $1985,6,131-136$.

[27] Muller, T., Marshall, R. J., Cooper, E. H., Watson, D. A. et al., Eur. J. Cancer Clin. Oncol. 1985, 21, 1461-1466.

[28] Birkle, S., Zeng, G., Gao, L., Yu, R. K., Aubry, J., Biochimie 2003, 85, 455-463.

[29] Black, P. H., N. Engl. J. Med. 1980, 303, 1415-1416.

[30] Valentino, L. A., Ladisch, S., Cancer Res. 1992, 52, 810-814.

[31] Hakomori, S., Cancer Res. 1996, 56, 5309-5318.

[32] Galea, H. R., Denizot, Y., Cogne, M., Cancer Immunol. Immunother. 2002, 51, 229-234.

[33] Redegeld, F. A., Heijden, M. W., Kool, M., Heijdra, B. M., Garssen, J., Nat. Med. 2002, 8, 694-701. 